\title{
Phylogenetic Analysis of Nucleotide Sequences from the ITS Region and Biological Characterization of Nematophagous Fungi from Morelos, Mexico
}

\author{
Gloria Sarahí Castañeda-Ramírez, ${ }^{1,2}$ Pedro Mendoza-de-Gives, ${ }^{1}$ \\ Liliana Aguilar-Marcelino, ${ }^{1}$ María Eugenia López-Arellano, ${ }^{1}$ \\ and Jesús Hernández-Romano ${ }^{2}$ \\ ${ }^{1}$ Helminthology Department, National Centre for Disciplinary Research in Veterinary Parasitology, CENID-Parasitología Veterinaria, \\ INIFAP, Boulevard Paseo Cuauhnáhuac No. 8534, Colonia Progreso, 62550 Jiutepec, MOR, Mexico \\ ${ }^{2}$ Department of Research, Polytechnic University of Morelos State (UPEMOR), Boulevard Paseo Cuauhnáhuac No. 566, \\ Colonia Lomas del Texcal, 62550 Jiutepec, MOR, Mexico
}

Correspondence should be addressed to Pedro Mendoza-de-Gives; pedromdgives@yahoo.com

Received 29 December 2015; Revised 13 March 2016; Accepted 3 April 2016

Academic Editor: Dagmar Triebel

Copyright (c) 2016 Gloria Sarahí Castañeda-Ramírez et al. This is an open access article distributed under the Creative Commons Attribution License, which permits unrestricted use, distribution, and reproduction in any medium, provided the original work is properly cited.

\begin{abstract}
We determined the morphological taxonomy of eighteen nematophagous fungi (NF), as well as their in vitro predatory activity against Haemonchus contortus infective larvae (L3). Fungi were classified into six genera and three species, the most common of which were Monacrosporium eudermatum and Arthrobotrys oligospora. We then sequenced five NF isolates using ITS4 and ITS5 primers. These sequences showed high identity with sequences from the NCBI database (98-99\%). In contrast, alignments among the same genera and species demonstrated 83-97\% identity. Polymorphisms observed between Arthrobotrys and Monacrosporium appear to be associated with differences in biological function, nonspecific mutations, evolutionary processes, feeding behaviour, predatory activity, and microecosystems.
\end{abstract}

\section{Introduction}

The livestock industry is commonly affected by gastrointestinal parasitic nematodiasis, which causes serious deterioration in the health of both cattle and sheep worldwide [1]. A number of methods of control have been proposed to reduce both the parasitic burden in the animals and the economic consequences for animal production; however, the only control method that is currently available in most countries is the regular administration of chemical anthelmintic drugs as deworming treatments. While such drugs help to reduce the parasitic burden in the animals, disadvantages can include the rising threat of inefficacy due to anthelmintic resistance and residues in animal products that are possibly toxic for human consumption and for the environment. For several years, therefore, alternative methods of control against parasites have been under investigation.
Nematophagous fungi are microorganisms in the soil that act as natural antagonists of nematodes and are considered potential biological control agents against agricultural plagues and ruminant parasitic nematodes. Using selected strains of nematophagous fungi for biotechnological purposes requires performing several studies to assess trapping efficiency against target nematodes. Precise taxonomic identification of nematophagous fungi isolates is the first step in selecting possible candidates to assess activity against nematodes in both laboratory and field trials. Traditional taxonomic identification of nematophagous fungi is based on microscopic observation and measurement of different fungal structures, that is, mycelia, spores, conidia, conidiophores, trapping devices, and other typical features [2]. Valuable taxonomic identification guides for nematophagous fungi were published by Drechsler, 1941 [3], Dollfus, 1946 [4], and Duddington, 1955 [5], and a highly descriptive and useful 


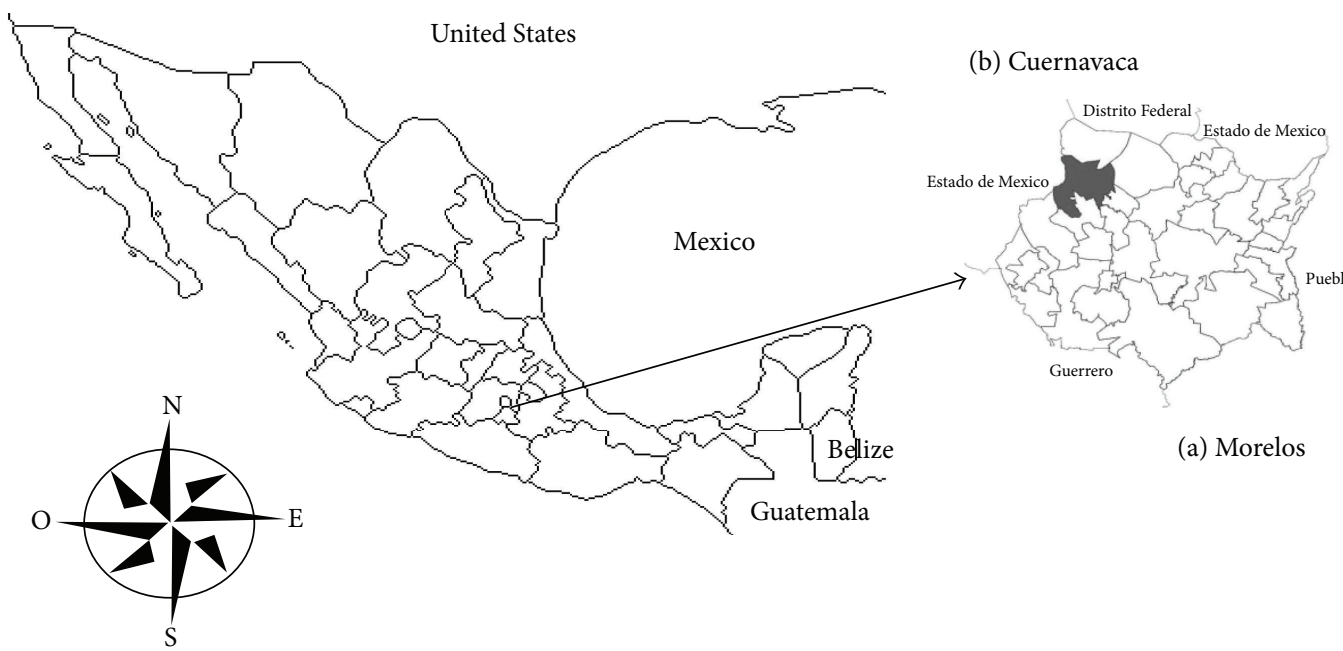

Figure 1: Map of the Mexican Republic: (a) the State of Morelos, (b) Cuernavaca City.

taxonomic key was published by Cooke and Godfrey [2]. More recently, taxonomic revisions concerning Dactylaria and the Dactylaria-Monacrosporium complex were published by de Hoog [6] and Rubner [7], respectively. These works are considered useful tools for taxonomic identification of nematophagous fungi. Nevertheless, this method of identification can be difficult because structures among fungal species are similar and can easily lead to confusion. For more precise taxonomic identification of nematophagous fungi, comparisons of $28 \mathrm{~S}$ rDNA, 5.8S rDNA, and $\beta$-tubulin gene sequences can be performed [8]. These molecular techniques can be used to identify target strains rapidly and accurately. Additionally, phylogenetic relationships among strains can be compared. Genotyping of nematophagous fungi is considered a valuable and accurate molecular tool for selection of fungi suitable for biotechnological purposes for the livestock and agricultural industries worldwide.

The state of Morelos in Mexico is rich in microflora and microfauna, though there is currently only limited information on nematophagous fungi at this location. This study, therefore, aimed to analyze the nucleotide sequences of the ITS regions of nematophagous fungi from Morelos, Mexico, for phylogenetic analysis and also to evaluate the biological activity of isolates against infective larvae of the sheep nematophagous nematode Haemonchus contortus.

\section{Materials and Methods}

2.1. Area of Study for Fungal Isolation. Soil sampling for fungal isolation was carried out at Northern Cuernavaca City in the state of Morelos, Southern Mexico City (Figure 1). Morelos possesses significant environmental diversity characterized by a rich variety of vegetation, including conifer and Quercus woodlands. Cuernavaca forms part of the Anahuac valleys and mountains, particularly the Chichinautzin mountain range slope. The northern part of Cuernavaca possesses a subhumid temperate climate with summer rains and high humidity and contains mesophilic woodlands of pine and oak trees. The yearly average temperature is $21.1^{\circ} \mathrm{C}$, with yearly average precipitation between 800 and $1,500 \mathrm{~mm}$. The highest temperatures $\left(24-28^{\circ} \mathrm{C}\right)$ occur in April and May. The lowest monthly temperature average (below $15^{\circ} \mathrm{C}$ ) occurs in December and January [9]. The soil is humic andosol and ocrico andosol derived from volcano ash that is adequate for forestry use (INAFED) [10, 11]. Such climate conditions promote the development of a wide diversity of floral and faunal species [11]. The high moisture and temperature as well as the soil characteristics that predominate in this woodland area are expected to trigger the proliferation of an important diversity of microorganisms with potential biotechnological uses. Nevertheless, there is no current information on the presence of microorganisms with potential biotechnological uses in this geographic region of Mexico.

Most samples were collected from the base of different tree species from the Santa María Ahuacatitlán Area. The geographic area was divided into two subareas: Zone 1 was characterized by a mixed woodland with oak trees, holm oak trees, and several types of pine trees, while Zone 2 was a woodland area consisting mainly of pine trees (Figure 2; Table 1).

2.2. Fungal Isolation. Samples (5 g) of soil, dry leaves, or compost were collected from every sampling site and transported to the lab. A previously described method of sprinkling soil on $2 \%$ agar plates for fungal isolation [12] was used. Each sample was sprinkled on the surface of $9 \mathrm{~cm}$ diameter water agar plates and incubated at room temperature (18$25^{\circ} \mathrm{C}$ ) and $60 \%$ humidity. After 2 days, an undetermined number of mixed stages of free-living nematodes (Panagrellus redivivus) were added to the agar surface of each plate to promote nematophagous fungal development. Every day after the third day, the incubation plate surface was viewed under a stereomicroscope to search for the presence of either nematophagous fungal aerial structures or trapped nematodes. Conidia or conidiophores were transferred with a fine, sterile needle to sterile water agar plates to isolate the observed fungi. This process was repeated as often as 


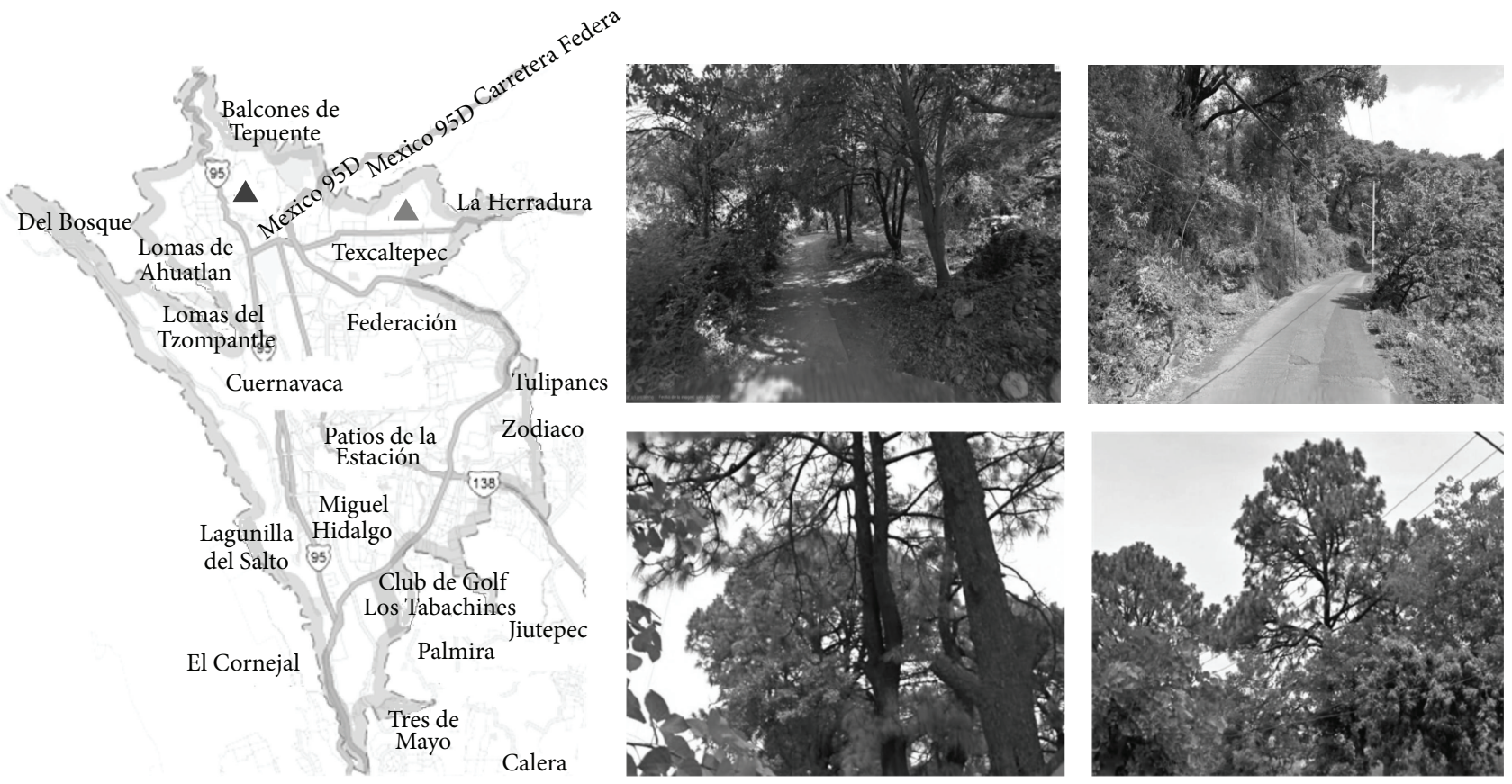

Figure 2: Map of Cuernavaca City. Triangles showing the area of sampling sites. Photos showing a view of woodlands predominant at Santa María Ahuacactitlán area, Cuernavaca, Morelos State, Mexico

TABLE 1: Sites and source of material collection for fungal isolation from Morelos, Mexico.

\begin{tabular}{|c|c|c|c|}
\hline \multicolumn{2}{|r|}{ Zone 1} & \multicolumn{2}{|c|}{ Zone $2(*)$} \\
\hline $\begin{array}{l}\text { Identification } \\
\text { number }\end{array}$ & Sampling sites & $\begin{array}{l}\text { Identification } \\
\text { number }\end{array}$ & Sampling sites \\
\hline 2.1 & Soil from the base of a tree (St Elena street) & 3.1 & Soil from a particular house \\
\hline 2.2 & Soil from a particular house (St Elena street) & 3.2 & Soil from the base of a pine tree \\
\hline 2.3 & $\begin{array}{l}\text { Soil from a sidewalk beside the street (St Elena } \\
\text { street) }\end{array}$ & 3.3 & Compost \\
\hline 2.4 & Soil + dry leaves (St Elena street) & 3.4 & Soil from the base of flowers \\
\hline 2.5 & $\begin{array}{l}\text { Soil from the Chichinautzin ecological corridor } \\
\text { entrance }\end{array}$ & 3.5 & Walking Corridor \\
\hline 2.6 & $\begin{array}{l}\text { Soil from Chichinautzin ecological corridor } \\
\text { sidewalk }\end{array}$ & 3.6 & Soils collected beside the rail train \\
\hline 2.7 & Soil from St. Maria club garden (St. Maria) & 3.7 & Soils collected beside the rail train \\
\hline 2.8 & $\begin{array}{l}\text { Soil from a garden at the Unión de las } \\
\text { Américas primary school }\end{array}$ & 3.8 & $\begin{array}{l}\text { Soil from orange colour dots in soil } \\
\text { (microbial consortium) }\end{array}$ \\
\hline 2.9 & $\begin{array}{l}\text { Soil collected beside the Mexico-Cuernavaca } \\
\text { highway }\end{array}$ & 3.9 & $\begin{array}{l}\text { Soil from gray colour dots in soil } \\
\text { (microbial consortium) }\end{array}$ \\
\hline 2.10 & $\begin{array}{l}\text { Soil from a particular garden beside the } \\
\text { Mexico-Cuernavaca highway }\end{array}$ & & \\
\hline 2.11 & Soil from the base of a monument (St. Maria) & & \\
\hline
\end{tabular}

(*) All sampling sites in Zone 2 are situated in Ahuatepec Alarcón community.

necessary until fungal isolates remained as pure culture. Once pure fungal cultures were obtained on water agar plates, fungi were transferred to potato dextrose agar plates and incubated for 20 days at room temperature $\left(18-25^{\circ} \mathrm{C}\right)$. After this period, abundant mycelia were produced on the agar surface. Mycelia were recovered from plates by scrapping the agar surface with a sterile spatula. The fungal material was eventually transferred into $1.5 \mathrm{~mL}$ microcentrifuge tubes and maintained at $-20^{\circ} \mathrm{C}$ until use.

\subsection{Fungal Identification through Traditional Taxonomy} (Morphometric System). Both the shapes and sizes of different fungal structures (conidia, conidiophores, trapping devices (traps), hyphae, and mycelia) were observed under 
a microscope. These structures were photographed (at 40x, $75 \mathrm{x}$, and 100x magnification) using a Leica Comax ${ }^{\circledR}$ CRC3141 colour camera CCD integrated with a microscope. Taxonomic identification of fungal genera and species was achieved following the identification keys published by Cooke and Godfrey [2], de Hoog [6], and Rubner [7].

2.4. Molecular Identification. DNA extraction was achieved following the methodology established for entomopathogenic fungi DNA extraction described by Tigano-Milani et al., 1995 [13]. The DNA amplification was achieved using PCR technique with the following primers: ITS5 (GGA AGT AAA AGT CGT AAC AAG G) and ITS4 (TCC TCC GCT TAT TGA TAT GC). These primers were used to amplify regions ITS1, 5.8S, and ITS2, as well as 18 S and 28S regions [14]. Amplicons of each fungal strain were obtained using the following mix reaction: DNA $5 \mu \mathrm{L}(100 \mathrm{ng} / \mu \mathrm{L})$, primers $2 \mu \mathrm{L}$ each $(100 \mathrm{ng} / \mu \mathrm{L}), \mathrm{MgCl}_{2} 2 \mu \mathrm{L}(2 \mathrm{mM})$, dNTP mix $1 \mu \mathrm{L}$ $(10 \mathrm{mM})$, buffer $5 \times 5 \mu \mathrm{L}$, and DNA Taq Polymerase $1 \mu \mathrm{L}(1 \mathrm{U})$ to obtain $25 \mu \mathrm{L}$ final volume. PCR conditions were an initial denaturation stage of $94^{\circ} \mathrm{C}$ for $10 \mathrm{~min}$, a second stage of 35 cycles of denaturation at $94^{\circ} \mathrm{C}$ for $60 \mathrm{sec}$, annealing at $60^{\circ} \mathrm{C}$ for 50 seconds and extension at $72^{\circ} \mathrm{C}$ for $90 \mathrm{sec}$, and a final extension stage at $72^{\circ} \mathrm{C}$ for $10 \mathrm{~min}$. PCR products were visualized by agarose gel electrophoresis. TAE $1 \mathrm{x}$ was used as a running buffer. The PCR products were purified using the Gel and PCR Clean-Up system kit (PROMEGA). The purified PCR products were quantified and individual sequencing reactions were prepared, using $100 \mathrm{ng}$ to $120 \mathrm{ng}$ by reaction. Sequencing was performed at the Institute of Biotechnology, UNAM, using an Applied Biosystems Sequencer (7700). Sequence homology analysis was done using the Basic Local Alignment Search Tool (BLAST) [15]. Identity percentages and mismatches count were obtained to confirm the traditional identification based on the morphology of fungal strains. A multiple aligning analysis was performed and analyzed separately to determine the similarity percentages between the selected fungal strains using ITS2 sequence. A total of 36 fungal sequences with different similarity levels were recovered from GenBank. ITS1, ITS2, and 5.8S segments were identified and ITS2 aligning was performed using the CLC Sequence Viewer software [16]. The gap cost and the extension cost were assigned as 10 and 1 , respectively. A phenogram was generated using the UPGMA algorithm with the Jukes-Cantor nucleotide distance measure and bootstrap analysis was done with 100 replicates. Additionally, a comparative matrix of transversions, transitions and inversions, was performed in order to compare the selected strains.

\subsection{Nematodes}

2.5.1. Panagrellus redivivus Free-Living Nematodes. A P. redivivus strain belonging to the CENID-Parasitología Veterinaria, INIFAP was used. Nematodes were produced in mass using a medium containing oat flakes and water [17]. Finally, the nematode suspension was transferred using the Baermann funnel technique to obtain a clean nematode suspension [12].
2.5.2. Haemonchus contortus (L3) Infective Larvae. A Mexican strain of the sheep parasitic nematode Haemonchus contortus from the INIFAP germplasm collection was used. A Pelibuey hair sheep was orally infected with the parasite to act as an "egg donor." After a 28-day prepatent period, nematode eggs were detected in the sheep's faeces through the McMaster technique [18]. Sheep faeces were directly collected from the rectum of the animal. Faecal material was processed to elaborate faecal cultures [19]. These cultures were incubated for 7 days at room temperature $\left(17-28^{\circ} \mathrm{C}\right)$. Each day, they were mixed with a wooden spoon and hydrated with tap water to promote maximum egg hatching and larva production. Larvae were extracted from faecal cultures using the Baermann funnel technique (for $24 \mathrm{~h}$ ) to eventually obtain a clean nematode suspension [12]. Residues and detritus were separated and removed from the larval suspension using the sucrose density gradient technique [20]. The larval suspension was washed three times using sterile water to remove sucrose residues. Finally, larvae were resuspended in sterile distilled water and kept at $4^{\circ} \mathrm{C}$ until use.

2.6. Fungal Predatory Activity Assessment. Every fungal strain was cultured in $5 \mathrm{~cm}$ Petri dishes containing $2 \%$ water agar $(n=10)$. After 7 days' incubation at room temperature $\left(25-28^{\circ} \mathrm{C}\right)$, approximately five hundred $H$. contortus infective larvae (L3) were added to the surface of each fungal plate. Additionally, a set of water agar plates $(n=10)$ without any fungi was used as a control and treated as described above. Later, the agar plate surface was viewed under a microscope (10x and $40 \mathrm{x})$ to visualize the predatory activity of fungi. The total number of larvae contained in each plate of each group was recovered through the Baermann funnel technique to assess fungal predatory activity.

The average number of recovered larvae was obtained and compared for both groups to estimate the percentage reduction in larvae due to the predatory action of the nematophagous fungi using the following formula [21]:

$$
A=\frac{X}{X+Y} * 100,
$$

where $A$ is reduction percentage, $X$ is average of recovered larvae from plates with fungi, and $Y$ is average of recovered larvae from plates without fungi.

2.7. Data Analysis. Data were analyzed using proofs of normality. A Kruskal-Wallis analysis with a completely random design was used [22]. The average number of recovered larvae from each of the two groups was considered as the variable/response. A multiple average comparison analysis was also performed using SAS [23]. An $\alpha$ value $=0.01$ was used.

2.8. Database Submission. The nucleotide sequences derived from the nematophagous fungi reported in this work were submitted to GenBank (accession numbers KC663623, KC663625, KC663626, KC663624, and KC663627). 
TABLE 2: Morphological and morphometric features of the different genera and species of nematophagous fungi isolated from soil samples from Northern Cuernavaca City, Morelos, Mexico.

\begin{tabular}{|c|c|c|c|c|c|}
\hline \multirow{2}{*}{ Genus/species strain } & \multicolumn{2}{|c|}{ Conidium size $(\mu \mathrm{m})$} & \multirow{2}{*}{$\begin{array}{l}\text { Conidiophore } \\
\text { length }(\mu \mathrm{m})\end{array}$} & \multirow{2}{*}{ Trapping devices } & \multirow{2}{*}{ Specific features } \\
\hline & Length & Width & & & \\
\hline M. eudermatum (Z-2.1) & $27.5-40$ & $15-20$ & 300 & \multirow{8}{*}{$\begin{array}{l}\text { Three-dimensional } \\
\text { adhesive nets }\end{array}$} & \multirow{8}{*}{$\begin{array}{l}\text { One single apical conidium, septum situated } \\
\text { at the middle conidium, segmented and } \\
\text { branched conidiophore }\end{array}$} \\
\hline M. eudermatum (Z-2.4) & $27.5-40$ & $15-20$ & 450 & & \\
\hline M. eudermatum (Z-3.1) & $25-42.5$ & $12-25$ & 400 & & \\
\hline M. eudermatum (Z-2.7) & $32.5-45$ & $15-22$ & 350 & & \\
\hline M. eudermatum (Z-3.3) & $27-42.5$ & $12-22$ & 370 & & \\
\hline M. eudermatum (Z-3.5) & $27.5-40$ & $15-22$ & 200 & & \\
\hline M. eudermatum (Z-3.6) & $27.5-40$ & $12-20$ & 300 & & \\
\hline M. eudermatum (Z-3.8) & $26-40$ & $13-21$ & 320 & & \\
\hline A. oligospora (Z-2.2) & $17.5-30$ & $12-20$ & 550 & \multirow{4}{*}{$\begin{array}{l}\text { Three-dimensional } \\
\text { adhesive nets }\end{array}$} & \multirow{4}{*}{$\begin{array}{l}\text { Conidiophores present conidia clusters; } \\
\text { septum situated below the middle conidium }\end{array}$} \\
\hline A. oligospora (Z-2.6) & $15-25$ & $10-12$ & 300 & & \\
\hline A. oligospora (Z-2.8) & $17.5-25$ & $10-12$ & 180 & & \\
\hline A. oligospora (Z-2.10) & $20-25$ & $7.5-12$ & 340 & & \\
\hline A. musiformis (Z-2.5) & $25-40$ & $7.5-15$ & 350 & \multirow{2}{*}{$\begin{array}{l}\text { Three-dimensional } \\
\text { adhesive nets }\end{array}$} & \multirow{2}{*}{$\begin{array}{l}\text { Elongated and segmented conidia; conidia } \\
\text { are produced from small denticles }\end{array}$} \\
\hline A. musiformis (Z-3.2) & $22.5-35$ & $7.5-12$ & 340 & & \\
\hline A. kirghizica (Z-2.9) & $15-22.5$ & $7.5-12$ & 340 & $\begin{array}{l}\text { Three-dimensional } \\
\text { adhesive nets }\end{array}$ & $\begin{array}{l}\text { Ovoid shape conidia; septum is situated } \\
\text { slightly below the middle conidium }\end{array}$ \\
\hline $\begin{array}{l}\text { T. globosporum var. } \\
\text { globosporum (Z-2.3) }\end{array}$ & $15-30$ & $7.5-15$ & 310 & \multirow{2}{*}{$\begin{array}{l}\text { Three-dimensional } \\
\text { adhesive nets }\end{array}$} & \multirow{2}{*}{$\begin{array}{l}\text { Conidium distal cell is larger; conidia are } \\
\text { frequently produced in clusters }\end{array}$} \\
\hline $\begin{array}{l}\text { T. g. var. globosporum } \\
(\mathrm{Z}-2.11)\end{array}$ & $22.5-30$ & $10-17$ & 350 & & \\
\hline T. g. var. roseum (Z-3.4) & $10-20$ & $10-20$ & 370 & $\begin{array}{l}\text { Three-dimensional } \\
\text { adhesive nets }\end{array}$ & Apiculated base, distal cell is longer \\
\hline
\end{tabular}

\section{Results}

3.1. Traditional Taxonomy. Morphological and morphometric taxonomic features of different fungal structures are shown in Table 2. Eighteen fungal isolates were obtained in total from the different geographic areas and from different substrates. Fungi were identified as belonging to three genera and six species of nematophagous fungi. Most of the fungal isolates corresponded to the species $M$. eudermatum (8 isolates); four isolates were identified as A. oligospora, two as A. musiformis, and one as A. kirghizica. Two isolates were determined as Trichothesium globosporum var. globosporum and one isolate as T. $g$. var. roseum (Table 2). Different morphological features of the nematophagous fungi are shown in Table 3.

3.2. In Vitro Predatory Activity of Nematophagous Fungi. Results of the assessment of the in vitro predatory activity of the nematophagous fungi against $H$. contortus infective larvae are shown in Table 4 . The larval reduction percentages recorded for the different isolates ranged between 32.4 and 96.7\%. The lowest predation percentages were observed for M. eudermatum (isolate Z-2.4) at $32.4 \%$ and A. kirghizica (Z-2.9) at $36.4 \%$. Species T. globosporum (Z-2.3, Z-2.11), A. oligospora (Z-2.6), A. musiformis (Z-2.5), and M. eudermatum (Z-2.1) showed moderate predation activities (59.1, 46.9, 56.2, 62.2 , and $67.6 \%$, resp.). The highest predatory activities were observed with T. globosporum var. roseum (Z-3.4) at 71.2\%, M. eudermatum (Z-3.6) at 74.3\%, M. eudermatum (Z-3.1) at $78.4 \%$, M. eudermatum (Z-3.8) at $85.4 \%$, M. eudermatum
(Z-3.3) at $91.53 \%$, A. oligospora (Z-2.8) at $93.07 \%, A$. oligospora (Z-2.10) at $94.6 \%$, M. eudermatum (Z-2.7) at $95.9 \%$, and A. oligospora (Z-2.2) at $96.7 \%$.

\subsection{Molecular Analysis}

3.3.1. Homology Analysis. The five isolates of nematophagous fungi that showed the highest in vitro predatory capability from among the 18 isolates, identified by traditional taxonomy as A. oligospora (Z-2.2, Z-2.8, and Z-2.10) M. eudermatum (Z-2.7, Z-3.3), were subject to molecular identification. PCR amplified fragments for Z-2.7 and Z-3.3 isolates were of $\approx 600 \mathrm{bp}$ length; fragments for Z-2.2, Z-2.8, and Z-2.10 isolates were observed near to $700 \mathrm{bp}$ length. The sequences derived from these PCR products were subject to a homology analysis, and percent identities of $98-99 \%$ obtained when the $18 \mathrm{~S}$ partial gene, ITS1 region, ribosomal 5.8S gene, ITS2 region, and ribosomal $28 \mathrm{~S}$ partial gene were compared. The morphometric taxonomic identification of the five selected nematophagous fungi was confirmed by the data from the molecular analysis (Table 5).

3.3.2. Transitions, Transversions and Insertions. Transitions occur more frequently than transversions; therefore, transitions and transversions were counted, as well as insertions, as a measure of evolutionary distance. The number of transitions between Z-2.2, Z-2.8 and Z-2.10, all classified as A. oligospora, varied from 3 to 5 , versus 11 to 16 between this group and Z-2.7 and Z-3.3, classified as M. eudermatum. Only one transversion was identified between Z-2.2, Z-2.8, and Z-2.10, 
TABLE 3: Microphotographs showing the aspect of different nematophagous fungi structures (conidia, conidiophore, and trapping devices) isolated from Morelos, Mexico. Scale bars $=20 \mu \mathrm{m}$.

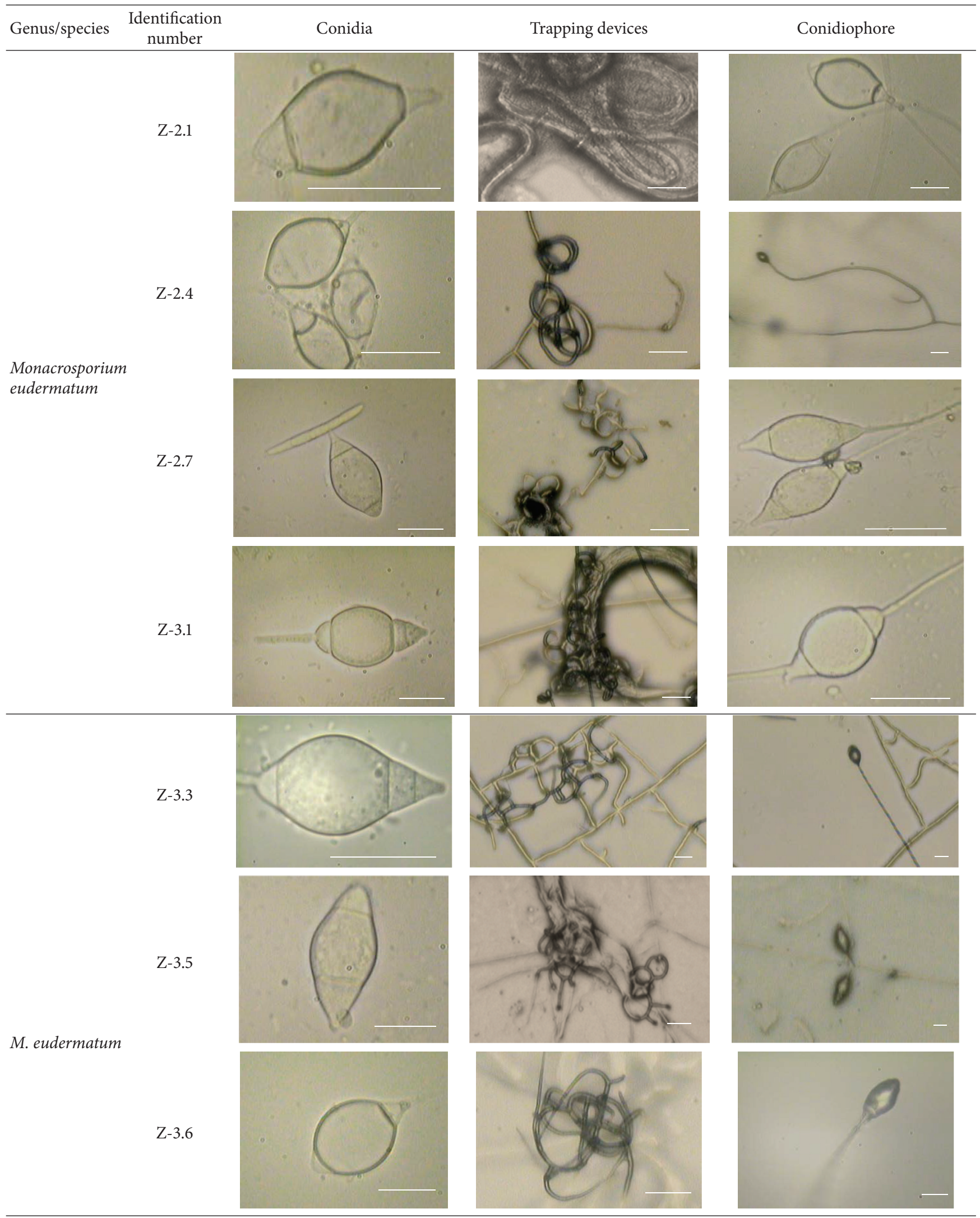


TABle 3: Continued.

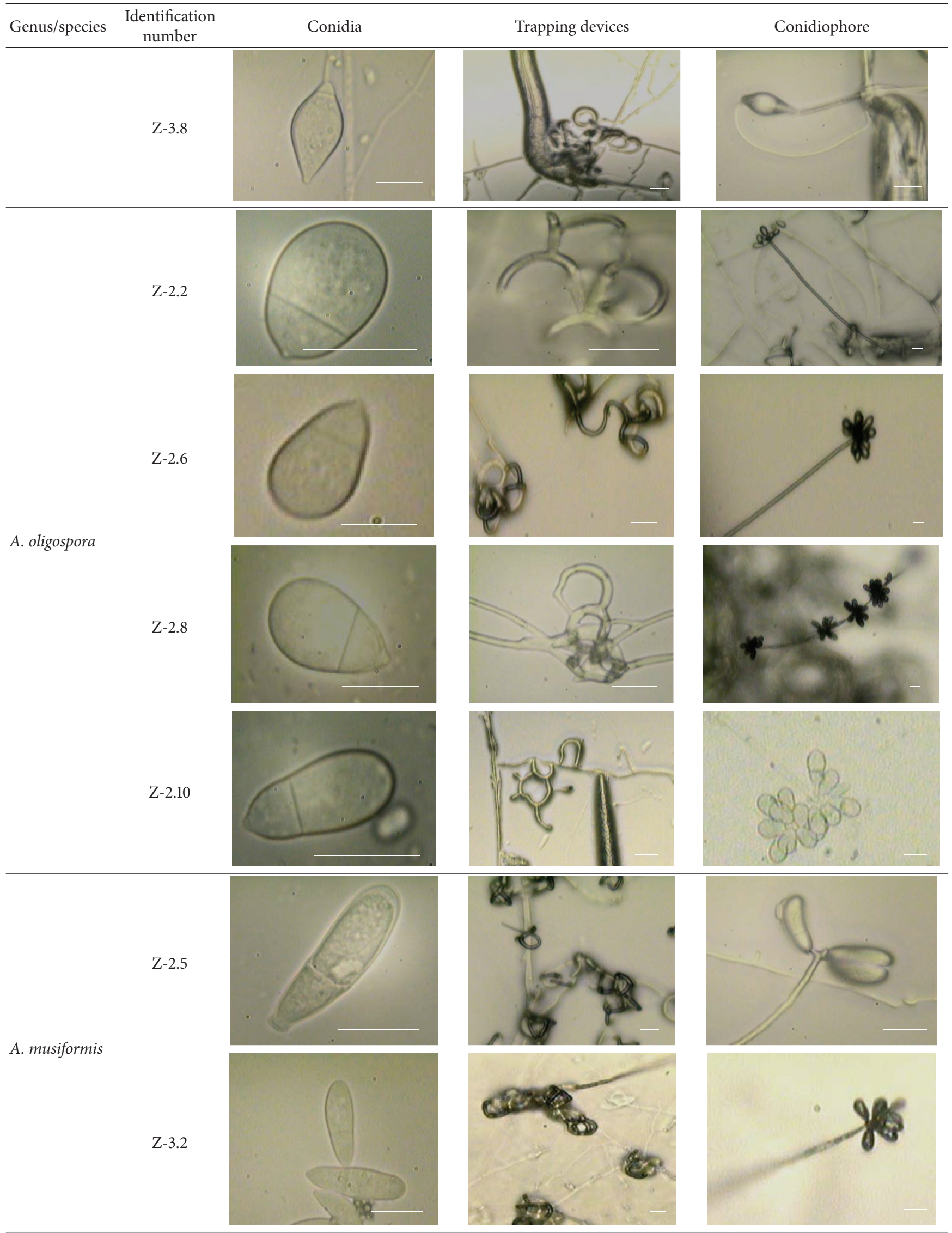


TABLE 3: Continued.

\begin{tabular}{|c|c|c|c|c|}
\hline Genus/species & $\begin{array}{l}\text { Identification } \\
\text { number }\end{array}$ & Conidia & Trapping devices & Conidiophore \\
\hline A. kirghizica & Z-2.9 & & & \\
\hline $\begin{array}{l}\text { Trichothecium } \\
\text { globosporum var. } \\
\text { globosporum }\end{array}$ & Z-2.3 & & & \\
\hline $\begin{array}{l}\text { T. g. var. } \\
\text { globosporum }\end{array}$ & Z-2.11 & & & \\
\hline T. g. var. roseum & Z-3.4 & & & \\
\hline
\end{tabular}

versus 15 to 18 between this group and Z-2.7 and Z-3.3. Three insertions were identified between Z-2.2, Z-2.8, and Z-2.10, versus 18 to 19 between this group and Z-2.7 and Z-3.3. No differences in these three features were detected between $Z$ 2.8 and Z-2.10 and between Z-2.7 and Z-3.3. The lack of differences in this region, which is not subject to selection pressure, suggests that these isolates are the same species or strains (A. oligospora and M. eudermatum, resp.). The correlation between molecular and traditional taxonomy is evident when the frequencies of transitions, transversions, and insertions are compared (Table 6).

3.3.3. ITS2 Sequence Analysis. A phenogram was generated using the ITS2 region that included the five selected nematophagous fungi isolates and homologous sequences with different similarity level (Figure 3). It shows a clear separation between the Arthrobotrys and Monacrosporium genera. The isolates Z-3.3 and Z-2.7 are located in the group of Monacrosporium (blue in Figure 3), and the isolates
Z-2.10, Z-2.8, and Z-2.2 are located within the Arthrobotrys group, which is in agreement with the morphological classification. Some organisms classified as Arthrobotrys are grouped with Monacrosporium, such as those associated with the accession numbers AY773459, EU3311088, and AY773451, among others; this observation suggests that these organisms could belong to the Monacrosporium genus. Inside of the Arthrobotrys group, two main branches are evident, the inferior branch includes the isolates Z-2.10, Z-2.8, and Z-2.2 reported in this work, which share the closest homology with sequences with accession numbers HQ649929 and AY773462, and the organism associated with the last sequence is classified as A. oligospora. Two other sequences also associated with $A$. oligospora (accession numbers GU799560 and HQ730901) are grouped separately. Similarly, not all the sequences associated with M. eudermatum are grouped together. These observations could indicate that there is a greater diversity than expected after morphological identification. 


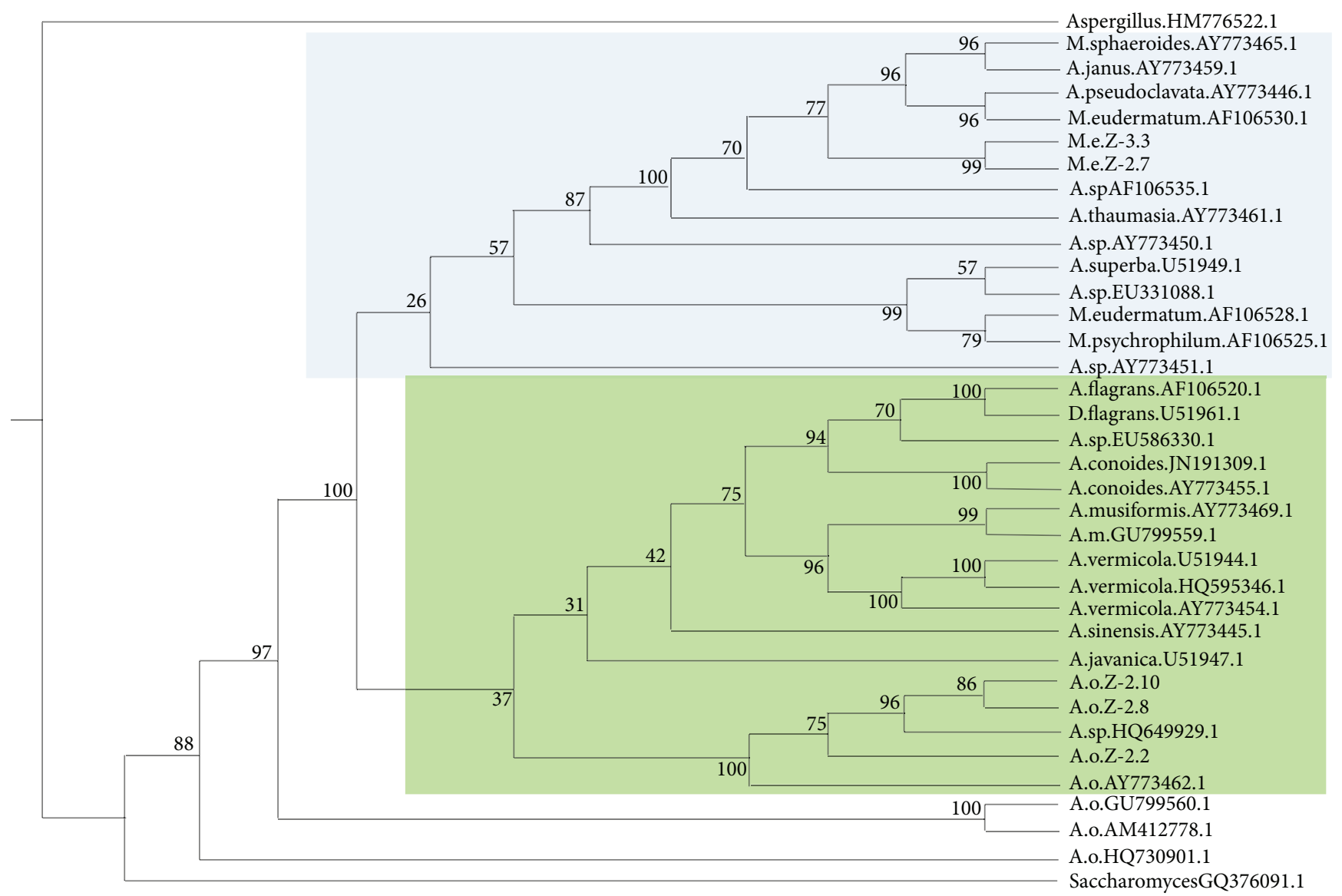

FIGURE 3: Phenogram generated using the ITS2 region that includes five selected nematophagous fungi isolates and homologous sequences with different similarity level.

\section{Discussion}

Nematophagous fungi are considered important tools for the control of parasitic diseases in both the agricultural and livestock industries worldwide. The present research shows evidence about the rich mycobiota of nematophagous fungi in soil from the studied area at Morelos, Mexico. The obtained fungal isolates show significant potential for use against Haemonchus contortus, which is one of the most pathogenic parasitic nematodes of ruminants around the world. The fungal species most commonly found was $M$. eudermatum. Some species of the Monacrosporium genus have been considered potential agents for control of animal parasitic diseases [2426]. Another species we identified was A. oligospora which is the most intensively studied nematophagous species worldwide and a number of important research works are published every year about its use against parasitic nematodes of either plants $[27,28]$ or animals $[29,30]$. A drastic structural change in the nematode cuticle when exposed to A. oligospora has been attributed to proteolytic enzyme activity produced by this species [31]. In addition, secondary metabolites with antibacterial activity produced by A. oligospora are currently being identified [14], giving this species additional biotechnological value. Knowledge of metabolic and chemical aspects of nematophagous fungi has led to important advances, and vanguard proposals on the genomics and proteomics of $A$. oligospora are currently being generated [32].

Another fungal species we identified was T. globosporum. In an extensive search on this species, only limited information could be found. Filtrates of different nematophagous fungi, including $T$. globosporum, were assessed to identify a possible hatching inhibition effect against the eggs of Meloidogyne incognita. More than $77 \%$ of $M$. incognita eggs were inhibited from hatching by the T. globosporum filtrate [20]. In the case of A. musiformis, several studies have been performed with this species and other genera/species. High capture and destruction efficiency against phytonematodes has been recorded, particularly against the causal agent of root gall, the nematode $M$. incognita, in tomato plants [33]. Similarly, this species has been assessed with other fungal species, and a high predatory activity (>97\%) against $H$. contortus has been recently recorded [34]. In general, the predatory activity of the nematophagous fungi obtained in the present study was variable. Some A. oligospora isolates (Z2.2 and Z-2.10), as well as M. eudermatum (Z-2.7) isolates, had high predatory activity $(>94 \%)$. Variable results have been reported with different $A$. oligospora isolates by other researchers. For example, a $93.3 \%$ rate of in vitro predatory 
TABLE 4: Mean number Haemonchus contortus infective larvae and reduction percentages recovered after 7 days' in vitro interaction with different nematophagous fungi isolates and reduction percentages.

\begin{tabular}{|c|c|c|c|c|}
\hline Fungal isolates & Control group $\bar{X}( \pm \mathrm{SD})$ & Treated group $\bar{X}( \pm \mathrm{SD})$ & Larvae reduction (\%) & Letters \\
\hline $\begin{array}{l}\text { Monacrosporium } \\
\text { eudermatum } \\
(\mathrm{Z}-2.1)\end{array}$ & $296 \pm 92.7$ & $96 \pm 50.6$ & 67.6 & $a, b, c, d, f, g$ \\
\hline $\begin{array}{l}\text { M. eudermatum } \\
\text { (Z-2.4) }\end{array}$ & $296 \pm 92.7$ & $200.1 \pm 13.14$ & 32.4 & $b, c, d, e, f, l$ \\
\hline $\begin{array}{l}\text { M. eudermatum } \\
\text { (Z-3.1) }\end{array}$ & $296 \pm 92.7$ & $64 \pm 42.99$ & 78.4 & $\mathrm{a}, \mathrm{b}, \mathrm{c}, \mathrm{d}, \mathrm{g}, \mathrm{h}, \mathrm{i}, \mathrm{k}$ \\
\hline $\begin{array}{l}\text { M. eudermatum } \\
\left(\mathrm{Z}-2.7^{*}\right)\end{array}$ & $296 \pm 92.7$ & $12 \pm 19.3$ & 95.9 & $\mathrm{~g}, \mathrm{i}, \mathbf{j}, \mathrm{k}$ \\
\hline $\begin{array}{l}\text { M. eudermatum } \\
\left(\mathrm{Z}-3.3^{*}\right)\end{array}$ & $520 \pm 253.7$ & $44 \pm 78.7$ & 91.5 & $\mathrm{a}, \mathrm{c}, \mathrm{g}, \mathrm{h}, \mathrm{i}, \mathbf{j}, \mathrm{k}$ \\
\hline $\begin{array}{l}\text { M. eudermatum } \\
\text { (Z-3.6) }\end{array}$ & $296 \pm 92.7$ & $76 \pm 60.1$ & 74.3 & $a, b, c, d, e, g, i, k$ \\
\hline $\begin{array}{l}\text { M. eudermatum } \\
\text { (Z-3.8) }\end{array}$ & $520 \pm 253.7$ & $76 \pm 74.1$ & 85.4 & $a, b, c, d, e, g, i, k$ \\
\hline $\begin{array}{l}\text { Arthrobotrys oligospora } \\
\left(\mathrm{Z}-2.2^{*}\right)\end{array}$ & $264 \pm 196$ & $8 \pm 25.9$ & 96.7 & $h, i, j, k$ \\
\hline $\begin{array}{l}\text { A. oligospora } \\
(\mathrm{Z}-2.6)\end{array}$ & $520 \pm 253.7$ & $228 \pm 101.63$ & 56.2 & $\mathrm{~d}, \mathrm{e}, \mathrm{f}, \mathrm{l}$ \\
\hline $\begin{array}{l}\text { A. oligospora } \\
\left(\mathrm{Z}-2.8^{*}\right)\end{array}$ & $520 \pm 253.7$ & $36 \pm 47.9$ & 93.1 & $\mathrm{a}, \mathrm{c}, \mathrm{g}, \mathrm{h}, \mathrm{j}, \mathbf{j}, \mathrm{k}$ \\
\hline $\begin{array}{l}\text { A. oligospora } \\
\left(\mathrm{Z}-2 \cdot 10^{*}\right)\end{array}$ & $520 \pm 253.7$ & $28 \pm 53.5$ & 94.6 & $\mathrm{a}, \mathrm{g}, \mathrm{h}, \mathrm{i}, \mathbf{j}, \mathrm{k}$ \\
\hline $\begin{array}{l}\text { A. musiformis } \\
(\mathrm{Z}-2.5)\end{array}$ & $296 \pm 92.7$ & $112 \pm 114.39$ & 62.2 & $a, b, c, d, e, f, g, i$ \\
\hline $\begin{array}{l}\text { A. kirghizica } \\
(\mathrm{Z}-2.9)\end{array}$ & $264 \pm 196$ & $168 \pm 117.45$ & 36.4 & $\mathrm{a}, \mathrm{b}, \mathrm{c}, \mathrm{d}, \mathrm{e}, \mathrm{f}, \mathrm{l}$ \\
\hline $\begin{array}{l}\text { Trichothecium } \\
\text { globosporum var. } \\
\text { (Z-2.3) }\end{array}$ & $264 \pm 196$ & $108 \pm 86.5$ & 59.1 & $a, b, c, d, e, f, g, i$ \\
\hline $\begin{array}{l}\text { Trichothecium } \\
\text { globosporum } \\
\text { (Z-2.11) }\end{array}$ & $264 \pm 196$ & $140 \pm 80.55$ & 46.9 & $\mathrm{a}, \mathrm{c}, \mathrm{d}, \mathrm{e}, \mathrm{f}, \mathrm{g}, \mathrm{l}$ \\
\hline $\begin{array}{l}T . \text { globosporum } \\
\text { var. roseum } \\
(\mathrm{Z}-3.4)\end{array}$ & $264 \pm 196$ & $76 \pm 36.02$ & 71.2 & a, b, c, d, e, g, i, k \\
\hline
\end{tabular}

$n=10, \mathrm{SD}=$ standard deviation

* Isolates selected based on their easy mass production and DNA extraction for molecular analysis.

Different literals in each column indicate statistic differences in the larvae reduction among the different fungal isolates $(p \leq 0.01)$.

a, b, c, d, e, f, and g literals indicate the significant comparison between means.

Statistical significance criteria were based on the Kruskal-Wallis analysis.

activity was found against $H$. contortus infective larvae for another A. oligospora isolate [34]; however, very low predation values $(37 \%)$ were obtained against the same parasitic nematode with another A. oligospora isolate [35]. In contrast, there is little information about the predatory activity of $M$. eudermatum, especially against ruminant parasitic nematodes.

In an in vitro trial, $M$. eudermatum, A. oligospora, and A. robusta conidia were mixed with sheep faeces containing H. contortus eggs; 95.7\%, 98.3\%, and 10.1\% larval reduction was recorded after 15 days' interaction [29]. Other nematophagous fungal species belonging to the Monacrosporium genus have been evaluated against sheep parasitic nematodes. The in vitro predatory activity of $M$. gephyropagum and A. robusta against Strongyloides papillosus resulted in $93.1 \%$ and $32.3 \%$ larval reductions, respectively [26]. Regarding the activity of $A$. musiformis, the results of our present research indicate a moderate in vitro larval reduction efficiency (62.1\%). In another work, this species showed a low predatory activity (40\%) against the same parasite/stage [35]. In contrast, this species has been previously reported to have high predatory activity (97\%) against the same parasite/stage [34]. 
TABLE 5: Identity percentages with the best hit of sequences containing 18S, ITS1, 5.8S, and ITS2 regions of five nematophagous fungi isolated in Morelos, Mexico, when they are used to do a homology search with BLASTn database. Accession numbers are given in brackets.

\begin{tabular}{lc}
\hline \multicolumn{2}{c}{ Nematophagous fungi sequence identification } \\
Fungi identification & Similarity percentages \\
\hline Z-2.2/A. oligospora & $98 \%$ with $A$. oligospora (AM412778) \\
Z-2.7/M. eudermatum & $98 \%$ with $M$. eudermatum (AF106530) \\
Z-2.8/A. oligospora & $99 \%$ with A. oligospora (AM412778) \\
Z-2.10/A. oligospora & $99 \%$ with A. oligospora (AM412778) \\
Z-3.3/M. eudermatum & $98 \%$ with $M$. eudermatum (AF106530) \\
\hline
\end{tabular}

On the other hand, A. kirghizica showed a low in vitro predatory activity (36.4\%) against the assessed nematode in the present study. This result is similar (35\%) to the one obtained in another study with the same species [35]. The predatory activity of A. kirghizica species has been evaluated as a biological control agent against agricultural nematode pests. This species was assessed with other genera/species of nematophagous fungi, that is, Trichothecium pravicoli and A. doliformis under field conditions. The three fungi showed high predatory activity against cucumber parasitic nematodes and root-gall nematodes were substantially reduced (90\%) [33].

The present research shows a large variability in predatory capability not only among nematophagous fungal species but also among different isolates from the same genera/species. Such a phenomenon could be due to nematophagous fungi possessing a natural "dual" feeding habit in which fungi can develop in two ways: either by feeding on vegetation residues where they obtain their Nitrogen source $\left(\mathrm{N}_{2}\right)$ from both plants and detritus in soil [12] or by obtaining their nutritional requirements from live nematodes. In the latter case, they become predator fungi [2]. The biological environments of nematophagous fungal isolates could differ in many respects, particularly the presence or absence of nematodes and the nematode population size. Such facts could determine the predatory or saprophytic behaviour of nematophagous fungi. Likewise, the five nematophagous fungi that were selected based on their high in vitro predatory activity (A. oligospora, isolates Z-2.2, Z-2.8, and Z-2.10 and M. eudermatum isolates Z-2.7 and Z-3.3) were sequenced and showed $100 \%$ identity to A. oligospora and M. eudermatum sequences from the GenBank-NCBI database. Phylogenetic and comparative analyses showed that the Z-2.10 and Z-2.8 isolates are virtually identical; aside from one transition and one insertion in the ITS1 region, no other change was found in either of the other two analyzed regions. However, these two sequences differ from the Z-2.2 isolate that came from the same site. It is important to highlight such differences because the three isolates are apparently identical from the morphological point of view and in agreement with the consulted taxonomic identification keys $[2,6,7]$. One possible explanation for the fact that some species of fungi are morphologically identical but show some molecular differences is that variants such as subspecies or varieties of fungi are under evolutionary processes influenced by environmental factors. The phylogram shows that two other sequences obtained from GenBank (http://www.ncbi.nlm.nih.gov/genbank/) coincide with the isolates selected in the present study. The $A$. oligospora Spanish strain (accession number HQ649929.1) is identical to the Mexican isolates (Z-2.10 and Z-2.8) from the present study; however, the Chinese strain (accession number AY773462.1) shows differences that confirm the presence of genetic diversity. A comparison of morphological features between these two isolates could be interesting to confirm the morphological variability. When conidia and conidiophores from Z-2.10 and Z-2.2 were compared under the microscope variability in length and width was observed, being Z-2.2 conidia wider and longer than Z-2.10, which confirm the morphological variation between the same fungal species. A more detailed molecular analysis must be carried out to achieve a more accurate classification of isolates from different parts of the world. The two M. eudermatum isolates were classified in a different group and were separated from other reported sequences for the same species (accession numbers AF106530 and AF106528) isolated from Germany. Similar to A. oligospora, there are differences in the DNA sequences that allow a more accurate classification of fungi. The results suggest that the current classification system (based on morphological characteristics) could mask a greater diversity among isolates belonging to the Arthrobotrys and Monacrosporium genera. Additionally, the assignation of isolates from different parts of the world to various species based only on morphological characteristics could produce inaccurate results. Similar studies on fungal predatory activity against ectoparasites including Beauveria, Verticillium, Paecilomyces, Tolypocladium, and Metarhizium suggest that there is intrageneric variation that has been associated with biological processes due to mitochondrial DNA (mtDNA) polymorphisms [36]. The polymorphism that we identified in Arthrobotrys and Monacrosporium in the present study could be attributed to differences in biological functions, unspecific mutations, evolutionary processes, predatory behaviour, and so forth. An example of such variability can be observed in the differences in trapping devices developed by the different nematophagous fungal strains $[32,37]$. During the evolution of $A$. musiformis, a point mutation in the $\beta$-tubulin gene produces an altered tubulin protein, whose major function is determining fungal cell structure. This mutation in A. musiformis affects fungal viability when exposed to anthelmintic compounds [37] and this mutation has been associated with A. musiformis polymorphism. In contrast, this mutation has not been found in other species of the genus Arthrobotrys. This fact suggests that diversity is present in the genus.

The present study identified a number of fungal isolates from Morelos, Mexico, with potential as biological control candidates for the livestock industry. The precise identification of nematophagous fungal isolates using traditional taxonomic methods complemented with molecular tools and characterization of biological activity against livestock parasites and ability to adapt to diverse laboratory conditions are vital features that must be considered in identifying elite 
TABLE 6: DNA modifications identified in the ITS2 regions of the nematophagous fungal isolates.

\begin{tabular}{|c|c|c|c|c|c|c|}
\hline Fungal isolates & Kind of change & $\begin{array}{c}\text { Z-2.2 } \\
\text { A. oligospora }\end{array}$ & $\begin{array}{c}\text { Z-2.7 } \\
\text { M. eudermatum }\end{array}$ & $\begin{array}{c}\mathrm{Z}-2.8 \\
\text { A. oligospora }\end{array}$ & $\begin{array}{c}\text { Z-2.10 } \\
\text { A. oligospora }\end{array}$ & $\begin{array}{c}\mathrm{Z}-3.3 \\
\text { M. eudermatum } \\
\end{array}$ \\
\hline \multirow{3}{*}{$\begin{array}{l}\mathrm{Z}-2.2 \\
\text { A. oligospora }\end{array}$} & Transitions & 0 & 12 & 5 & 3 & 11 \\
\hline & Transversions & 0 & 18 & 1 & 1 & 18 \\
\hline & Insertions & 0 & 19 & 3 & 3 & 18 \\
\hline \multirow{3}{*}{$\begin{array}{l}\text { Z-2.7 } \\
\text { M. eudermatum }\end{array}$} & Transitions & & 0 & 16 & 16 & 0 \\
\hline & Transversions & & 0 & 15 & 16 & 0 \\
\hline & Insertions & & 0 & 24 & 24 & 0 \\
\hline \multirow{3}{*}{$\begin{array}{l}\mathrm{Z}-2.8 \\
\text { A. oligospora }\end{array}$} & Transitions & & & 0 & 0 & 16 \\
\hline & Transversions & & & 0 & 0 & 16 \\
\hline & Insertions & & & 0 & 0 & 24 \\
\hline \multirow{3}{*}{$\begin{array}{l}\text { Z-2.10 } \\
\text { A. oligospora }\end{array}$} & Transitions & & & & 0 & 16 \\
\hline & Transversions & & & & 0 & 16 \\
\hline & Insertions & & & & 0 & 24 \\
\hline \multirow{3}{*}{$\begin{array}{l}\text { Z-3.3 } \\
\text { M. eudermatum }\end{array}$} & Transitions & & & & & 0 \\
\hline & Transversions & & & & & 0 \\
\hline & Insertions & & & & & 0 \\
\hline
\end{tabular}

strains to be used as potential candidates for the control of parasites in livestock.

\section{Competing Interests}

The authors declare that they have no competing interests.

\section{Acknowledgments}

The present paper is dedicated to the memory of Dr. Enrique Liébano Hernández, who collaborated in the present research.

\section{References}

[1] R. M. Barragán, V. A. Ruiz, J. R. Rodríguez, and L. J. G. Márquez, "Grazing sheep poisoned by milkweed Asclepias curassavica or gastrointestinal nematosis? A case report findings," Veterinaria México, vol. 40, no. 3, pp. 275-281, 2009.

[2] R. C. Cooke and B. E. S. Godfrey, "A key to the nematodedestroying fungi," Transactions of the British Mycological Society, vol. 47, no. 1, pp. 61-74, 1964.

[3] C. Drechsler, "Predaceous fungi. Biological review," Cambridge Philosophy Society, vol. 16, no. 4, pp. 265-290, 1941.

[4] R. P. Dollfus, Parasites (Animal et Vegetaux) des helminthes, Paul Lechevalier, Paris, France, 1946.

[5] C. L. Duddington, "Fungi that attack microscopic animals," The Botanical Review, vol. 21, no. 7, pp. 377-439, 1955.

[6] G. S. de Hoog, "Taxonomy of the Dactylaria complex, IV. Dactylaria, Neta, Subulispora and Scolecobasidium," Studies in Mycology, vol. 26, pp. 1-60, 1985.

[7] A. Rubner, "Revision of predacious hyphomycetes in the Dactylella-monacrosporium complex," Studies in Mycology, vol. 1996, no. 39, pp. 1-134, 1996.

[8] Y. Li, K. D. Hyde, R. Jeewon, L. Cai, D. Vijaykrishna, and K. Zhang, "Phylogenetics and evolution of nematode-trapping fungi (Orbiliales) estimated from nuclear and protein coding genes," Mycologia, vol. 97, no. 5, pp. 1034-1046, 2005.

[9] INEGI, 2011, http://www3.inegi.org.mx/sistemas/mexicocifras/.

[10] INAFED (Instituto Nacional Para el Federalismo y el Desarrollo Municipal, Gobierno del Estado de Guerrero): 2005, Fecha de consulta: 08 de Diciembre 2015, http://www.inafed.gob.mx/ work/enciclopedia/EMM17morelos/index.html.

[11] INAFED (Instituto Nacional Para el Federalismo y el Desarrollo Municipal, Gobierno del Estado de Morelos, March 2012, http:// www.inafed.gob.mx/work/enciclopedia/EMM12guerrero/.

[12] G. L. Barron, The Nematode-Destroying Fungi. Topics in Microbiology, Canadian Biological Publications no. 1, Department of Environmental Biology, University of Guelph, Ontario, Canada, 1977.

[13] M. S. Tigano-Milani, R. J. Honeycutt, L. A. Lacey, R. Assis, M. Mcclelland, and B. W. S. Sobral, "Genetic variability of Paecilomyces fumosoroseus isolates revealed by molecular markers," Journal of Invertebrate Pathology, vol. 65, no. 3, pp. 274-282, 1995.

[14] T. J. White, T. D. Bruns, S. B. Lee, and J. W. Taylor, "Amplification and direct sequencing of fungal ribosomal RNA genes for phylogenetics," in Protocols: A Guide to Methods and Application, M. A. Innis, D. H. Gelfand, J. J. Sninsky, and T. J. White, Eds., pp. 315-322, Academic Press, New York, NY, USA, 1990.

[15] S. F. Altschul, W. Gish, W. Miller, E. W. Myers, and D. J. Lipman, "Basic local alignment search tool," Journal of Molecular Biology, vol. 215, no. 3, pp. 403-410, 1990.

[16] Sequence Viewer software, http://www.clcbio.com/index.php? $\mathrm{id}=28$.

[17] R. de Lara, T. Castro, J. Castro, and G. Castro, "Cultivo de nematodo Panagrellus redivivus (Goodey, 1945) en un medio de avena enriquecida con Spirulina sp.," Revista de Biología Marina y Oceanografía, vol. 42, no. 1, pp. 29-36, 2007.

[18] D. Thiempont, F. Rochete, and O. F. J. Vanparijs, Diagnosing Helminthiasis by Coprological Examination, Jansen Research Foundation, Beerse, Belguim, 1986. 
[19] F. Valcárcel, F. A. Rojo, A. S. Olmeda, B. Arribas, L. Márquez, and N. Fernández, Atlas de Parasitología Ovina, Grupo Asis Biomedia, Zaragoza, Spain, 2009.

[20] H. S. Zawam, H. M. Abdelnabby, M. S. Manal, and M. S. Abeer, "Effect of different fungal filtrates and spores on Meloidogyne incognita under laboratory and greenhouse conditions," Egyptian Journal of Applied Science, vol. 25, no. 1, pp. 111-124, 1999.

[21] J. A. Casillas-Aguilar, P. Mendoza-de-Gives, M. E. LópezArellano, and E. Liébano Hernández, "Evaluation of multinutritional pellets containing Duddingtonia flagrans chlamydospore for the control of ovine haemonchosis," Annals of the New York Academy of Sciences, vol. 1149, pp. 161-163, 2008.

[22] R. G. D. Steel and J. H. Torrie, Bioestadística: Principios y Procedimientos, MacGraw-Hill/Interamericana de México, 2nd edition, 1988.

[23] SAS Institute, Language Guide for Personal Computer Release. 6.03 Edition, SAS Institute, Cary, NC, USA, 1998.

[24] F. Braga, J. Milani, N. Araujo et al., "Destruction of Strongyloides venezuelensis infective larvae by fungi Duddingtonia flagrans, Arthrobotrys robusta and Monacrosporium sinense," Revista da Sociedade Brasileira de Medicina Tropical, vol. 44, no. 3, pp. 389391, 2011.

[25] R. O. Carvalho, J. V. Araújo, F. R. Braga et al., "Biological control of Ancylostomosis in dogs using the nematode-trapping fungus Monacrosporium thaumasium in southeastern Brazil," Veterinary Parasitology, vol. 165, no. 1-2, pp. 179-183, 2009.

[26] M. E. Gonzalez Cruz, P. Mendoza-de-Gives, and H. Quiroz Romero, "Comparison of the trapping ability of Arthrobotrys robusta and Monacrosporium gephyropagum on infective larvae of Strongyloides papillosus," Journal of Helminthology, vol. 72, no. 3, pp. 209-213, 1998.

[27] T. Khan, S. Shadab, R. Afroz, A. Aziz, and F. Mazahar, "Study of suppressive effect of biological agent fungus, natural organic compound and carbofuran on root knot nematode of tomato (Lycopersicon esculentum)," Journal of Microbiology and Biotechnology Research, vol. 1, no. 1, pp. 7-11, 2011.

[28] N. Piedra, "Manejo biológico de nematodos fitoparásitos con hongos y bacterias," Tecnología en Marcha, vol. 21, no. 1, pp. 123132, 2008.

[29] P. Mendoza-de Gives and V. M. Vázquez-Prats, "Reduction of Haemonchus contortus infective larvae by three nematophagous fungi in sheep faecal cultures," Veterinary Parasitology, vol. 55, no. 3, pp. 197-203, 1994.

[30] C. Saumell, L. Fusé, L. Iglesias, S. Fernández, and C. Fiel, "Enfoque bioecológico del potencial de los hongos nematófagos en el control biológico de Tricostrongilídeos de rumiantes," Revista de Medicina Veterinaria (Buenos Aires), vol. 89, no. 2, pp. 45-54, 2008.

[31] Z. Minglian, M. Minghe, and Z. Keqin, "Characterization of a neutral serine protease and its full-length $\mathrm{cDNa}$ from the nematode-trapping fungus Arthrobotrys oligospora," Mycologia, vol. 96, no. 1, pp. 16-22, 2004.

[32] J. Yang, L. Wang, X. Ji et al., "Genomic and proteomic analyses of the fungus Arthrobotrys oligospora provide insights into nematode-trap formation," PLoS Pathogens, vol. 7, no. 9, Article ID e1002179, 2011.

[33] S. Shipinova, "Studies of the use of predatory fungi for control of the root knot nematode," Phytonematology, vol. 546, pp. 38-41, 1964.

[34] I. C. Alfaro-Gutiérrez, P. Mendoza-de-Gives, E. LiébanoHernández, M. E. López-Arellano, R. O. Valero-Coss, and V.
M. Hernández Velázquez, "Nematophagous fungi (Orbiliales) capturing, destroying and feeding on the histotrophic larvae of Haemonchus contortus (Nematoda: Trichostrongylidae)," Revista Mexicana de Micología, vol. 33, pp. 29-35, 2011.

[35] P. M. C. Acevedo-Ramírez, H. Quiroz-Romero, R. O. ValeroCoss, P. Mendoza-de-Gives, and J. L. Gómez, "Nematophagous fungi from Mexico with activity against the sheep nematode Haemonchus contortus," Ibero-Latinoamericana de Parasitolog $\varphi$ a, vol. 70, no. 1, pp. 101-108, 2011.

[36] D. D. Hegedus and G. G. Khachatourians, "Identification of molecular variants in mitochondrial DNAs of members of the genera Beauveria, Verticillium, Paecilomyces, Tolypocladium, and Metarhizium," Applied and Environmental Microbiology, vol. 59, no. 12, pp. 4283-4288, 1993.

[37] J. B. Chauhan, R. Swetha, B. Jarullah, and R. Subramanian, "Isolation and molecular characterization of $\beta$-tubulin gene from Arthrobotrys," Indian Journal of Biotechnology, vol. 6, no. 3, pp. 404-406, 2007. 

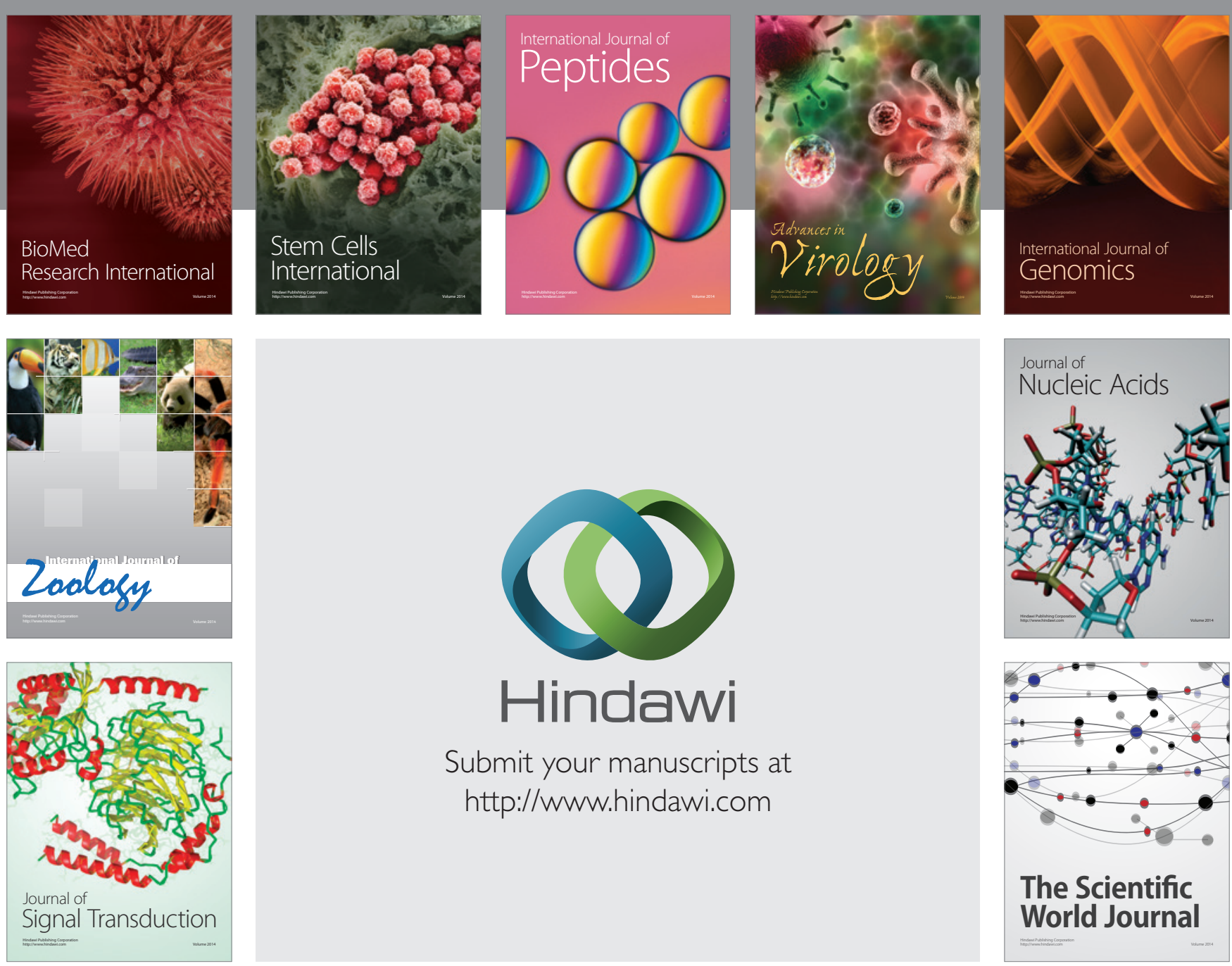

Submit your manuscripts at

http://www.hindawi.com
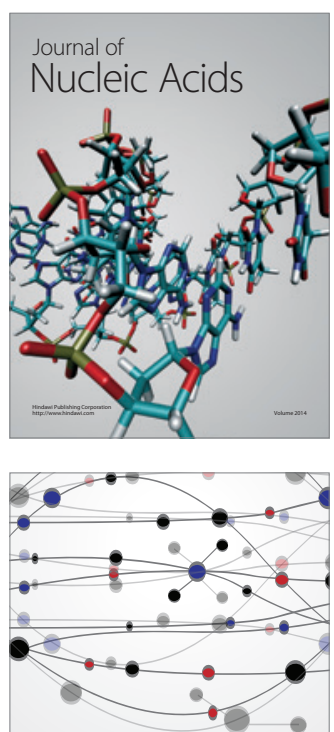

The Scientific World Journal
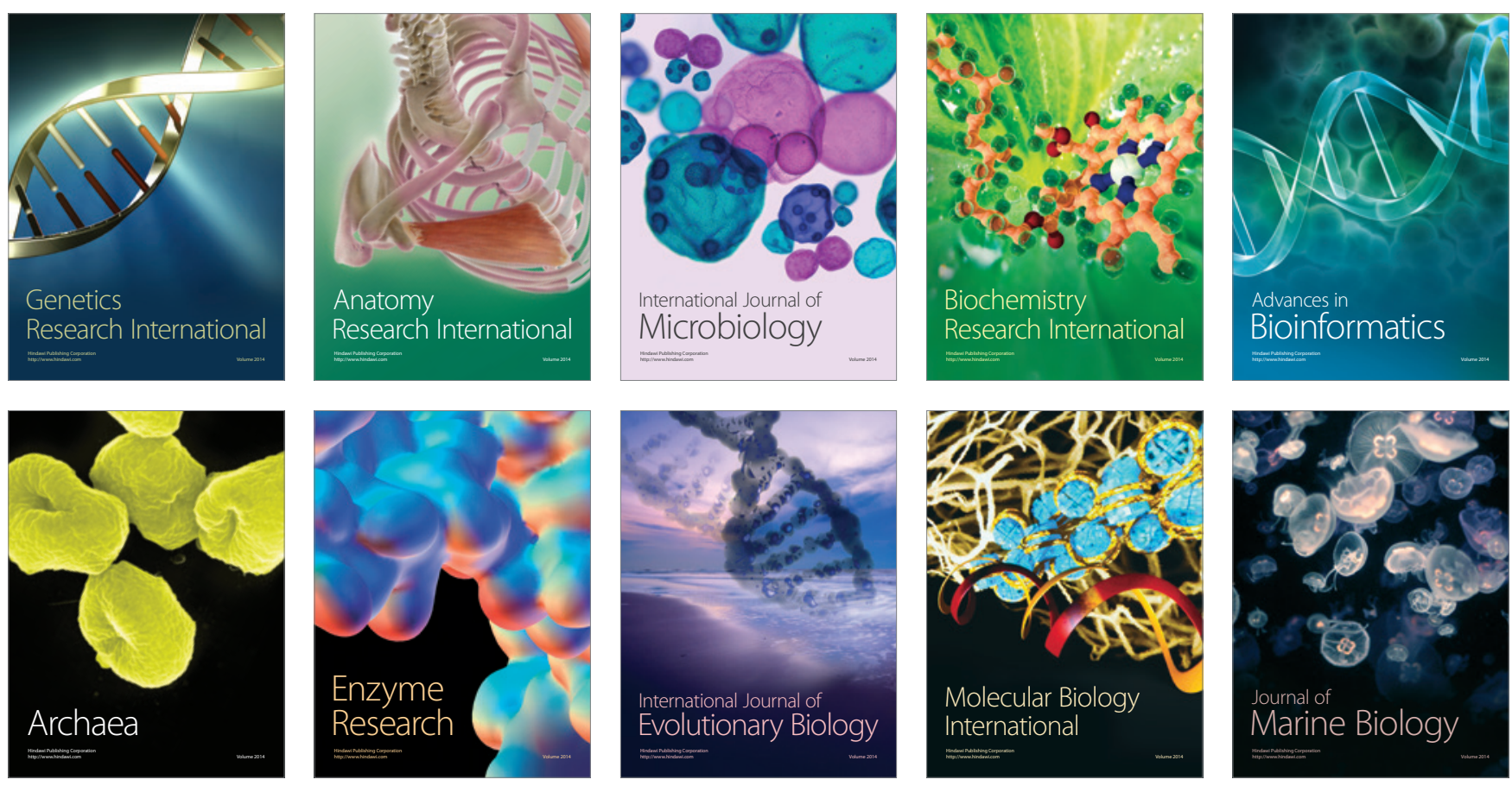